\title{
Gamma Ray Shielding Properties of Some Concrete Materials
}

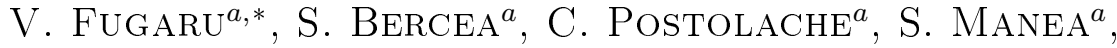

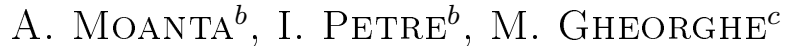 \\ ${ }^{a}$ Horia Hulubei National Institute for Physics and Nuclear Engineering, 30 Reactorului St., \\ Bucharest-Magurele, jud. Ilfov, P.O.B. MG-6, 077125, Romania \\ ${ }^{b}$ CEPROCIM S.A. 6 Preciziei blvd., Bucharest, 062203, Romania \\ ${ }^{c}$ Technical University of Civil Engineering of Bucharest, \\ 122-124 Lacul Tei blvd, 020396, Bucharest, Romania
}

\begin{abstract}
Concrete of various type have been used extensively for the adequate shielding of the radiological equipment using $\mathrm{X}$ and gamma rays. In its basic form, concrete is composed of pieces of inert aggregate held together by hardened cement paste. Different concrete types with special cements have been prepared. The linear attenuation coefficients of conventional concrete and concrete with supplementary mineral additives (barite and witherite) at different gamma energies (Co-60: $1.25 \mathrm{MeV}$, Cs-137: $0.662 \mathrm{MeV}$, Ir-192: $0.37 \mathrm{MeV}$ ) in narrow beam conditions have been measured. This paper includes some experimental data regarding the influence of barite and witherite additives on photon attenuation coefficients of concrete.
\end{abstract}

DOI: $10.12693 /$ APhysPolA.127.1427

PACS: $28.52 . \mathrm{Fa}$

\section{Introduction}

The installations that use X-ray and sealed gamma ray sources up to $10 \mathrm{MeV}$ for medical and non-medical purposes are one of many sources of risk associated with radiation. The primary factor involved in $\mathrm{X}$ and gamma radiation shielding is the reduction of the intensity of the radiation to the desired level in order to keep the exposure of the persons to radiation to levels as low as reasonable achievable and secondary to this, there are economical and mechanical factors, which are interrelated to a considerable extent. Concrete, both of normal and special types, is the most commonly used shield material, due to the fact that it is an effective, versatile and economic material for the construction of any nuclear facilities. Concrete, in its basic form, is composed of pieces of inert aggregate held together by hardened cement paste. The concrete shielding properties depends on the composition the concrete. Various types of concrete have been developed ranging from ordinary Portland cement concrete to barite and witherite concrete. While ordinary or conventional concrete in sufficient thickness will provide satisfactory shielding, heavy concrete, made from special aggregates is often preferable due to smaller thickness requirement. Industrial by product such fly ash, slag, and granule blast furnace are used as supplementary cementing materials and as result, to reduce environmental pollution. Mineral additives added in concrete, as barite $\left(\mathrm{BaSO}_{4}\right)$ or witherite $\left(\mathrm{BaCO}_{3}\right)$, which are well photon radiation absorbent, can improve the attenuation parameters for gamma ray as linear attenuation coefficient $\left(\mu, \mathrm{cm}^{-1}\right)$ and mass attenuation coefficient $(\mu / \rho$, $\left.\mathrm{cm}^{2} / \mathrm{g}^{-1}\right)[1]$.

\footnotetext{
* corresponding author; e-mail: vfugaru@nipne.ro
}

There are a lot of studies in literature concerning the radiation shielding properties of the different types of normal and heavy concrete [2].

In this study, linear attenuation coefficient of gamma rays of conventional concrete and concrete with supplementary mineral additives (barite and witherite) at energies of $1.25 \mathrm{MeV}, 0.662 \mathrm{MeV}, 0.37 \mathrm{MeV}$ and mass attenuation coefficients of each sample have been determined.

\section{Materials and methods}

The concrete has been modeled experimentally so as to be highlighted, the more realistic, the gamma radiation shielding performance cements. Thus, we designed and carried out identical concrete compositional parameters, referring to water to cement ratio (as low as possible), and to aggregates volume and particle size distribution. The only variable was the type of cement. The materials used to obtain concretes were special cements with the ability oo shielding gamma radiation, natural river aggregates (fine and coarse) and high range water reducers (HRWR) superplasticizers. The HRWR, based on the modified polyether carboxylate, Premia 180 Chryso and Chryso Fluid Optima 206, have had a major contribution to the decrease of the water to cement ratio $(\mathrm{W} / \mathrm{C})$ as a key factor for increasing concrete compactness as a significant property for the increase of the gamma radiation shielding. Three different series of concrete have been prepared, maintaining constant quantitative compositional parameters respectively, the $\mathrm{W} / \mathrm{C}$ ratio, the ratio and the dosage of cement and aggregate. Proportions of all mixture ingredients used are given in Table I.

In Table I the concrete mixtures are designed based on the following code: Cement $\mathrm{E}=\mathrm{CEM} 1$, Cement $\mathrm{B} 2=\mathrm{CEM} 1$ with $20 \% \mathrm{BaSO}_{4}$, Cement $\mathrm{BC} 2=\mathrm{CEM} 1$ with $20 \% \mathrm{BaCO}_{3}, \mathrm{EC}=$ ordinary concrete, $\mathrm{B} 2 \mathrm{C}$ and $\mathrm{BC} 2 \mathrm{C}=$ concrete with $\mathrm{B} 2$ and respectively $\mathrm{BC} 2$ cement. 
The concrete mixes with the special cements.

TABLE I

\begin{tabular}{c|c|c|c|c|c}
\hline \hline $\begin{array}{c}\text { Concrete } \\
\text { code }\end{array}$ & $\begin{array}{c}\text { Cement } \\
\text { dosage } \\
{\left[\mathrm{kg} / \mathrm{m}^{3}\right]}\end{array}$ & $\begin{array}{c}\text { Sand } \\
{\left[\mathrm{kg} / \mathrm{m}^{3}\right]} \\
0-4 \mathrm{~mm}\end{array}$ & $\begin{array}{c}\text { Coarse } \\
{\left[\mathrm{kg} / \mathrm{m}^{3}\right]} \\
4-16 \mathrm{~mm}\end{array}$ & $\begin{array}{c}\text { HRWR } \\
\text { Superplasticizer } \\
{[\%]}\end{array}$ & $\begin{array}{c}\text { W/C } \\
\text { Ratio }\end{array}$ \\
\hline $\mathrm{EC}$ & 375 & 703 & 1147 & 1.6 & 0.38 \\
$\mathrm{~B} 2 \mathrm{C}$ & 375 & 703 & 1147 & 1.6 & 0.38 \\
$\mathrm{BC} 2 \mathrm{C}$ & 375 & 703 & 1147 & 1.6 & 0.38
\end{tabular}

Concrete mixtures were poured in parallelepiped moulds with the dimensions of $210 \times 300 \mathrm{~mm}$ and thicknesses of 20,40,70 and $100 \mathrm{~mm}$. The concrete plate was placed between detector and source, and the distance source-detector was of $86 \mathrm{~cm}$. The equivalent dose rate of the radioactive source was determined, with and without the concrete plate between the source and the detector, for each type and thickness of concrete sample using flow meter Eberline FH-40-GL model. The following radioactive sealed source has been used: Iridium-192, mean gamma energy $0.37 \mathrm{MeV}$ ); Cesium-137, gamma energy $0.662 \mathrm{MeV}$ and Cobalt-60, mean gamma energy $1.25 \mathrm{MeV}$. The radioactive source was shielded by pinhole collimators to achieve the narrow beam condition. The measurements were repeated 10 times in order to decrease the statistical errors.

Gamma ray attenuation coefficients, $\mu$, have been evaluated according to the exponential attenuation law

$$
I(x)=I_{0} \exp (\mu / x),
$$

where $I_{0}$ is the incident intensity of photons penetrating a layer of material of thickness $x$ and $I$ is the emerging intensity of photons.

The schematic arrangement of the experimental setup is illustrated in Fig. 1.

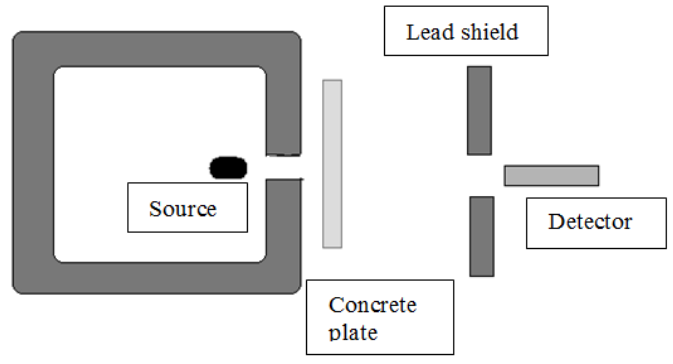

Fig. 1. Experimental setup.

\section{Results and discussion}

The physical and mechanical characteristics of the special cements $\mathrm{E}, \mathrm{B} 2$ and $\mathrm{BC} 2$, which have been used in this study and have been determined according to SRN 197-1, are presented in Table II.

The densities of each type of the concrete obtained, EC (ordinary concrete), B2C (concrete with barite) and $\mathrm{BC} 2 \mathrm{C}$ (concrete with witherite) were: $2.38 \mathrm{~g} / \mathrm{cm}^{3}$, $2.45 \mathrm{~g} / \mathrm{cm}^{3}$ and $2.40 \mathrm{~g} / \mathrm{cm}^{3}$.

The concrete mixtures were prepared using the same compositional parameters, referring to $\mathrm{W} / \mathrm{C}$ ratio and to aggregates volume and particle size distribution.
Physical and mechanical properties of the

TABLE II cements E, B2, and BC2.

\begin{tabular}{c|c|c|c}
\hline Characteristic & $\begin{array}{c}\text { Cement } \\
\mathrm{E}\end{array}$ & $\begin{array}{c}\text { Cement B2 } \\
\text { (barite 20\%) }\end{array}$ & $\begin{array}{c}\text { Cement B2C } \\
\text { (witherite) }\end{array}$ \\
\hline $\begin{array}{c}\text { Setting time: } \\
\text { beginning [min] }\end{array}$ & 190 & 300 & 280 \\
\hline $\begin{array}{c}\text { Setting time: } \\
\text { end time [hrs.-min] }\end{array}$ & $4-00$ & $6-30$ & $7-00$ \\
\hline $\begin{array}{c}\text { Flexural strength } \\
2 \text { days, [MPa] }\end{array}$ & 5.5 & 4.0 & 4.0 \\
\hline $\begin{array}{c}\text { Flexural strength } \\
28 \text { days [MPa] }\end{array}$ & 8.7 & 7.4 & 6.8 \\
$\begin{array}{c}\text { Compressive strength } \\
2 \text { days, [MPa] }\end{array}$ & 28.0 & 17.9 & 18.2 \\
\hline $\begin{array}{c}\text { Compressive strength } \\
28 \text { days, [MPa] }\end{array}$ & 52.0 & 42.2 & 42.4 \\
\hline
\end{tabular}

The $\mathrm{W} / \mathrm{C}$ ratio, which is inversely related to concrete strength, was decreased by adding in concrete mixtures high water reducer superplasticizers [3].

To investigate the effect of adding barite or witherite in concrete composition on gamma radiation shielding properties, the photon attenuation was determined by measuring the ratio of transmission of the penetrating radiation through concrete samples (equivalent dose rate ratio). Plotting the logarithmic form of Eq. 1 versus different $x$, a straight line was obtained. The linear attenuation coefficient, $\mu$, was obtained using the value of the slope [4].

The linear attenuation coefficients for concrete types produced with special cements have been measured at photon energies of $1.37 \mathrm{MeV}, 0.661 \mathrm{MeV}$, and $1.25 \mathrm{MeV}$. The experimental results are listed in Table III.

\begin{tabular}{|c|c|c|c|}
\hline & Ir-192 & Cs-137 & Co-60 \\
\hline $\mathrm{EC}$ & 0.202 & 0.167 & 0.120 \\
\hline $\mathrm{B} 2 \mathrm{C}$ & 0.212 & 0.175 & 0.128 \\
\hline $\mathrm{BC} 2 \mathrm{C}$ & 0.216 & 0.178 & 0.126 \\
\hline
\end{tabular}

\section{Conclusion}

The linear attenuation coefficient is one of the most important parameter which characterizes the radiation shielding properties of the concrete. In this study, the gamma ray attenuation of ordinary concrete and concrete with special cement (barite and witherite as additives) has been determined. The shielding properties of the concrete samples have been studied in the gamma field emitted by three radioactive sources: Ir-192, Cs-137 and Co-60 [5].

As a conclusion the linear attenuation coefficient slightly increases, about $3-7 \%$, for concrete with special cement compare to conventional concrete. The linear attenuation coefficients $\mu$ decreases with increasing gamma ray energy for all the concrete types studied [6]. 
The results show that there is no significant difference between photons attenuation for barite concrete and witherite concrete at energies $1.25 \mathrm{MeV}, 0.661 \mathrm{MeV}$ and $0.37 \mathrm{MeV}$.

\section{Acknowledgments}

Tha research has ben supported by the Project PNCDI II 177/2012 and Core Project No 09370206 from Executive Unit for Financing Education Higher Research Development and Innovation of Romania.

\section{References}

[1] R.L. Whitte, J.E. Backstrom, "Properties of Heavy Concrete with Barite Aggregates" in Concrete for Radiation Shielding, edited by American Concrete Institute, Detroit 1965.
[2] M.F. Kaplan, Concrete for Radiation Shielding, edited by Longman Scientific and Technology, Longman Group, Essex, England 1989.

[3] M.H. Kharita, S. Yousef and M. Al-Nassar, Progress in Nuclear Energy 52, 491 (2010).

[4] F. Demir, G. Budak, A. Karabulut, M. Oltulu, A. Un, Annals Nuclear Energy 38, 1274 (2011).

[5] A.A. Al-Bayati, Indian J. Phys. 78A, 1405 (2004).

[6] E. Ylmaz, H. Baltas, E. Kiris, U. Cevick, A.M. ElKhayatt, Annals Nuclear Energy 38, 2204 (2011). 